\title{
Barberry in the treatment of obesity and metabolic syndrome: possible mechanisms of action
}

This article was published in the following Dove Press journal: Diabetes, Metabolic Syndrome and Obesity:Targets and Therapy

\author{
Safieh Firouzi ${ }^{1,2, *}$ \\ Mahsa Malekahmadi ${ }^{1,2, *}$ \\ Majid Ghayour-Mobarhan ${ }^{1,3}$ \\ Gordon Ferns ${ }^{4}$ \\ Hamid Reza Rahimi ${ }^{3,5}$ \\ 'Metabolic Syndrome Research \\ Center, Mashhad University of \\ Medical Sciences, Mashhad, Iran; \\ ${ }^{2}$ Student Research Committee, \\ Mashhad University of Medical \\ Sciences, Mashhad, Iran; ${ }^{3}$ Department \\ of Modern Sciences and Technology, \\ Faculty of Medicine, Mashhad \\ University of Medical Sciences, \\ Mashhad, Iran; ${ }^{4}$ Department of \\ Medical Education, Brighton and \\ Sussex Medical School, University of \\ Brighton Falmer Campus, Brighton, \\ UK; ${ }^{5}$ Neurogenic Inflammation \\ Research Center, Mashhad University \\ of Medical Sciences, Mashhad, Iran
}

*These authors contributed equally to this work

Correspondence: Majid

Ghayour-Mobarhan

Khorasan Razavi, Mashad, Azadi Square,

University of Pardis, Faculty of Medicine,

91777 , Mashhad, Iran

Tel +985I 38002301

Fax +985I 838002287

Email Ghayourm@mums.ac.ir

Hamid Reza Rahimi

Neurogenic Inflammation Research

Center, Mashhad University of Medical

Sciences, Mashhad, Iran

Tel +985I 3800230 I

Fax +9851838002287

Email Rahimihr@mums.ac.ir

\begin{abstract}
Obesity is a consequence of an imbalance between energy intake and energy expenditure. It affects people of both genders and all age groups, ethnicity and socioeconomic groups, and in developed and developing countries. Obesity is often accompanied by the metabolic syndrome (MetS). MetS is characterized by a clustering of cardiovascular risk factors, including high blood pressure, adiposity, dyslipidemia and glucose intolerance, which together increase the risk of atherosclerotic cardiovascular disease, type 2 diabetes mellitus and other causes of mortality. Nowadays, there is a growing interest in the use of plant-based agents instead of synthetic drugs to manage chronic diseases such as MetS; one such example is Berberis vulgaris. B. vulgaris contains isoquinonline alkaloids such as berberine, berberrubine and berbamine. Recent studies have proved that berberine exhibits pharmacological activities and positive effects on the risk factors of obesity and MetS. We have reviewed original articles related to the possible molecular mechanisms of action of berberine on obesity and MetS. Berberine suppresses adipocyte differentiation and decreases obesity. It also regulates glucose metabolism via decreasing insulin resistance and increasing insulin secretion. Other effects of berberine include antihyperlipidemic and antihypertensive activities and endothelial protection.
\end{abstract}

Keywords: berberine, syndrome metabolic, obesity

\section{Introduction}

Obesity is a consequence of an imbalance between energy intake and energy expenditure. The WHO has identified obesity as a major public health problem because of its associated risk for a number of noncommunicable diseases, which include type 2 diabetes mellitus, hypertension, dyslipidemias and cardiovascular disease, and a reduction in life expectancy. ${ }^{1}$ Overweight, obesity and morbid obesity are usually defined using body mass index (defined as the weight in kilograms divided by the height in meters squared) of 25-29.9, 30-39.9 and $>40$, respectively. Other more sophisticated methods for directly assessing body fat, or adiposity, include bioelectrical impedance analysis, computed tomography and MRI. ${ }^{2}$ Abdominal obesity is an independent predictor of several cancer- and cardiovascular-related outcomes and can be assessed relatively simply by measuring waist circumference or waist-to-hip ratio. ${ }^{3}$ Obesity is a common public health problem, which is causing an estimated around 2.6 million deaths in the world. ${ }^{2}$ It affects all age, sex, ethnic and socioeconomic groups in both developed and developing countries. ${ }^{4}$ Obesity is a multifactorial disorder due to an interaction between genetic, socioeconomic, environmental and behavioral influences. ${ }^{5}$ Differences in energy metabolism may play a role in long-term body weight regulation 
and the pathogenesis of human obesity. Several prospective studies have shown that relatively low energy expenditure and high respiratory quotient due to a low fat to carbohydrate oxidation rate predict body weight gain. ${ }^{6}$ Obesity is often accompanied by the metabolic syndrome (MetS). MetS is determined by a series of factors including physiological, biochemical, clinical and metabolic parameters that together enhance the risk of atherosclerotic cardiovascular disease, type 2 diabetes mellitus and other causes of mortality. ${ }^{7}$ There are several definitions of MetS, but some of the most popular definitions are from the $\mathrm{WHO}^{8}$ and the National Cholesterol Education Program Adult Treatment Panel III. ${ }^{9}$

According to the National Cholesterol Education Program Adult Treatment Panel III definition for MetS, the presence of any three of the following five features including waist circumference $\geq 102 \mathrm{~cm}$ in men or $\geq 88 \mathrm{~cm}$ in women, $\geq 130 / 85$ $\mathrm{mmHg}$ (includes hypertensive patients and patients who received antihypertensive medications), triglyceride (TGs) $\geq 150 \mathrm{mg} / \mathrm{dL}$, high-density lipoprotein cholesterol $<40 \mathrm{mg} /$ $\mathrm{dL}$ in men or $<50 \mathrm{mg} / \mathrm{dL}$ in women and fasting blood glucose $\geq 100 \mathrm{mg} / \mathrm{dL}$ (includes diabetes).

The prevalence of MetS varies widely $(10 \%-84 \%)$ and depends on the region, urban or rural setting, individual characteristics, including sex, age, race and ethnicity of the population studied, and the definition of the syndrome used. ${ }^{10,11}$ The International Diabetes Federation estimates that MetS affects approximately one-quarter of the world's adult population. ${ }^{12}$ Therefore, many strategies for prevention are being developed to reduce the future MetS burden. Nowadays, there is a growing preference to use plant-based agents instead of synthetic drugs to manage chronic diseases such as MetS because plantbased agents have fewer adverse effects and lesser costs and are more accessible than synthetic drugs in some countries. ${ }^{13}$ Studies show that formulations of one-quarter of all medical prescriptions are derived from plant synthetic analogs, and according to the WHO, $80 \%$ of the world population, especially in developing countries, trust in plant-based medicines. ${ }^{13}$

Berberis vulgaris (zereshk in Persian) is widely cultivated in Iran (particularly in South Khorasan province), central and southern Europe and northeastern US. ${ }^{14,15}$ B. vulgaris has been used in herbal therapy for $>2,500$ years, mainly by Russian therapists. ${ }^{16}$ The antioxidants present in berberry include berberine, berberrubine and berbamine. ${ }^{17}$ Berberine is an alkaloid that is used in Chinese medicine. This herbal ingredient exists in the stem, roots, rhizomes and seven plant species such as Berberis vulgaris, Berberis aristata, Mahonia aquifolium, Hydrastis canadensis, Xanthorhiza simplicissima, and Phellodendron amurense (barberry). ${ }^{12}$
Berberine affects the glucose metabolism by increasing glycolysis and increasing insulin sensitivity, ${ }^{18}$ and a recent study has suggested that berberine is both anti-inflammatory and anti-adipogenic. The anti-adipogenic effect may be a result of the downregulation of transcription factors and adipogenic enzymes. ${ }^{19}$ Berberine is also used in the treatment of diarrhea, stomatitis, dysentery and hepatitis. ${ }^{20}$

The polyphenols in barberry juice have been reported to have a positive effect on lipid profiles and diabetes complications. ${ }^{21,22}$

The chemical structure of berberine is shown in Figure 1.

\section{Inclusion of studies}

The keywords including "berberine", "diabetes", "insulinresistance", "glucose", hemoglobin A1C", "dislipidemia", "obesity" and "atherosclerosis" were used for an electronic search strategy. All the identified studies and review articles were reviewed. Subsequently, the eligible trials were selected. These are papers reporting original studies on the antidiabetic, antihyperlipidemic and anti-adipogenic mechanisms of action of berberine and almost all available clinical trials. But we mentioned this study is not systematic review.

\section{The mechanisms of action of berberine in obesity}

Adipocyte differentiation requires several transcription factors, and key regulators in the process are two adipogenic factors, CCAAT/enhancer-binding protein $\alpha(\mathrm{C} / \mathrm{EBP} \alpha)$ and peroxisome proliferator-activated receptor $\gamma$ (PPAR $\gamma$ ). The PPARs function as lipid sensors and regulate lipid and lipoprotein metabolism, glucose homeostasis, adipocyte proliferation and differentiation. ${ }^{23} \mathrm{C} / \mathrm{EBPa}$-deficient cells are capable of adipocyte differentiation and are also insulin resistant. ${ }^{24}$ It has been discovered that GATA factors play a role in adipogenesis. ${ }^{25}$ GATA-2 and GATA-3 are expressed in adipocyte precursors and control the preadipocyte to adipocyte transition. Berberine reduces the expression of C/EBPa and PPAR $\gamma$ and it has been shown to inhibit

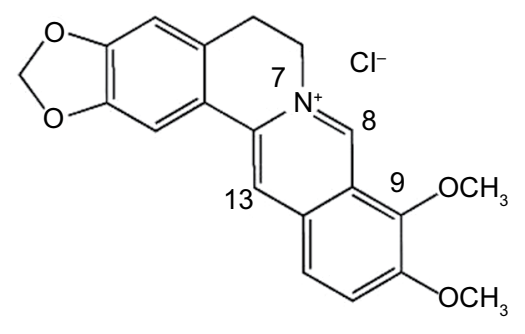

Figure I Chemical structure of berberine. 
the differentiation of 3T3-L1 cells in murine-derived preadipocytes and human white preadipocytes. ${ }^{26}$ Furthermore, berberine increases the expression of GATA-2 and GATA-3 and these suppress adipocyte differentiation. ${ }^{24}$ This mechanism is directly through binding to the PPAR $\gamma$ promoter and suppression of basal activity of PPAR $\gamma$. Also, GATA-2 and GATA-3 form a protein complex with C/EBPa that suppresses the transcriptional activity of PPAR $\gamma .{ }^{27}$ It has been reported that berberine reduces weight, the food intake, the ratio of epididymal fat to total weight, as well as the ratio of liver weight to total weight in a murine model. In addition, blood glucose, TG and total cholesterol levels were all reduced in high fat-fed obese mouse, revealing that berberine acts as a potential natural compound for the treatment of obesity. ${ }^{26}$ The accumulation of TG in adipose tissue leads to obesity, and therefore, reducing the amount of TG in adipocytes may be a way for decreasing obesity. One study showed that berberine increased the adipose TG lipase expression in 3T3-L1 adipocytes and it led to reduced TG accumulation in adipocytes. Berberine also reduced the numbers and size of lipid droplets in 3T3-L1 adipocytes. ${ }^{28}$

Several studies have shown that berberine regulates TG, cholesterol and glucose metabolism via AMP-activated protein kinase (AMPK) expression, ${ }^{29}$ an important regulator of lipolysis in adipose tissue. Hormone-sensitive lipase and adipose TG lipase are phosphorylated by AMPK. ${ }^{30,31}$

\section{The effects of berberine on insulin resistance and glycemic control}

Berberine has been shown to regulate glucose and lipid metabolism in vitro and in vivo (see Table 1). It enhances insulin secretion, stimulating glycolysis, suppressing adipogenesis by inhibiting PPAR $\gamma$ and $\mathrm{C} / \mathrm{EBP} \alpha$ function, ${ }^{32}$ activating the AMPK pathway and increasing glycokinase activity. Berberine stimulates pancreatic $\mathrm{G}$ protein-coupled receptor 40 (GPR40), reduces intestinal glucose absorption by inhibiting $\alpha$-glucosidase activity, and also upregulates the expression of glucose transporter-4 (GLUT-4) and stimulates glucose uptake, and upregulates glucagon like peptide-1 (GLP-1) genes. ${ }^{33,34}$

\section{Secretagogue effect of berberine on insulin}

Berberine increases glucose-stimulated insulin secretion in a dose-dependent manner, enhancing both mRNA expression of hepatic nuclear factor 4-alpha (HNF-4 $\alpha$ ) and glycokinase activity; this provides an insulinotropic effect different from sulfonylureas. ${ }^{35}$
Table I Glycemic control mechanisms of berberine

\begin{tabular}{|l|}
\hline Upregulation of GLUT-4 \\
\hline Activation of AMPK \\
\hline Suppression of adipogenesis by inhibiting PPAR $\gamma$ and C/EBP $\alpha$ function \\
\hline Stimulation of GLP-I \\
\hline Suppression of human protein tyrosine phosphatase IB \\
\hline Stimulation of the pancreatic GPR40 \\
\hline $\begin{array}{l}\text { Reduction of intestinal glucose absorption by inhibiting } \alpha \text {-glucosidase } \\
\text { activity }\end{array}$ \\
\hline
\end{tabular}

Abbreviations: AMPK, 5' adenosine monophosphate-activated protein kinase; GLP-I, glucagon-like peptide-I; GLUT-4, glucose transporter type 4; GPR40, G protein-coupled receptor 40 .

\section{Berberine and insulin resistance}

In 3T3-L1 adipocytes, with insulin resistance, berberine could inhibits IKB kinase beta (IKKbeta) Ser(181) and IRS-1 Ser(307) phosphorylation, and could progress glucose transport induced by insulin and rebound insulin resistance due to free fatty acids. ${ }^{36}$ It also improves insulin sensitivity by upregulating IRS-2 mRNA expression in the expression of PPAR- $\alpha / \delta$ and decreases the expression of PPAR- $\gamma$ in the liver of diabetic rat $^{37}$ and is also related to the suppression of adipocyte differentiation. ${ }^{38}$ Also, berberine enhances insulin sensitivity by reducing the homeostatic model assessmentinsulin resistance value up to $50 \%{ }^{34}$

\section{Antihyperlipidemic activity of berberine}

Berberine stabilizes low-density lipoprotein (LDL)-R mRNA by reducing the LDL-R mRNA 3' UTR binding of heterogeneous nuclear ribonucleoprotein I and KH-type splicing regulatory protein, which are key modulators of LDL-R mRNA stability in liver cells. ${ }^{39}$ Berberine also enhances the transcriptional activity of LDL-R promoter by c-Jun N-terminal kinase (JNK) pathway ${ }^{40}$ and reduces the transcription of the PCSK9 gene, the product of which induces LDL-R degradation. ${ }^{41}$ Furthermore, berberine decreases the activities of PPAR- $\gamma$, fatty acid synthase, acetyl-CoA carboxylase, acyl-CoA synthase and lipoprotein lipase. ${ }^{42}$ Also, berberine decreases lipid profiles by improving the liver function and bile acid secretion, and polyphenolic compound in barberry juice can justify the positive effects on lipid profiles. ${ }^{43}$

\section{Antihypertensive and endothelium protection effects of berberine}

The effects of berberine on vasodilation of vessels has been shown in different rat models. ${ }^{44,45}$ Berberine affects both endothelium and vascular smooth muscle. The vasorelaxant effect of berberine is endothelium dependent at low concen- 
trations $\left(<1 \times 10^{6} \mathrm{M}\right)$, but endothelium independent at higher concentrations. ${ }^{46,47}$ Barberry juice contains some vasodilator factors such as berberine, this substance effects on the central nervous system and reduce blood pressure. ${ }^{43}$ Regarding the possible mechanism of barberry on blood pressure, it is suggested that barberry may induce the production of nitric oxide and, thus, vasodilatation. ${ }^{48}$ Berberine enhances the expression of endothelial nitric oxide synthase mRNA and suppresses the expression of inducible nitric oxide synthase mRNA in gastric tissue ${ }^{49}$ and inhibits angiotensin converting enzyme..$^{50}$
Berberine-induced endothelium-independent relaxation appears to occur by the activation of tetrapentylammonium4-aminopyridine- and $\mathrm{Ba}(2+)$-sensitive $\mathrm{K}(+)$ channels, inhibition of intracellular $\mathrm{Ca}(2+)$ release from caffeine-sensitive pools or as a direct relaxant effect. ${ }^{46}$

In rat models, the nephroprotective effect of berberine was shown to reduce hypertension. ${ }^{40}$ Berberine preserved endothelial functions by maintaining the reactive and elastic features of vessels. In this connection, berberine suppresses platelet-derived growth factor (PDGF)-induced vascular smooth muscle cell growth by activating AMPK/p53/p21

Table 2 Clinical efficacy of barberry

\begin{tabular}{|c|c|c|c|c|c|}
\hline $\begin{array}{l}\text { Author } \\
\text { (publication year) } \\
\text { Country }\end{array}$ & Patient (number) & Study design & Intervention & Duration & $\begin{array}{l}\text { Results } \\
\text { Significant reduction } \\
(P<0.05)\end{array}$ \\
\hline $\begin{array}{l}\text { Lazavi et al }(2018)^{43} \\
\text { Iran }\end{array}$ & $\begin{array}{l}\text { Patients with type } 2 \\
\text { diabetes }(n=45)\end{array}$ & $\begin{array}{l}\text { Randomized } \\
\text { clinical trial }\end{array}$ & $200 \mathrm{~mL}$ of barberry juice/day & 8 weeks & $\begin{array}{l}\text { FBG, TC, blood pressure: } \\
\text { both systolic and diastolic, } \\
\text { TGs }\end{array}$ \\
\hline $\begin{array}{l}\text { Zilaee et al }(2015)^{48} \\
\text { Iran }\end{array}$ & $\begin{array}{l}\text { Subjects with } \\
\text { metabolic syndrome } \\
(n=106)\end{array}$ & $\begin{array}{l}\text { Double-blind } \\
\text { controlled trial }\end{array}$ & $\begin{array}{l}200 \mathrm{mg} \text { (capsule) three times } \\
\text { per day }\end{array}$ & 6 weeks & $\begin{array}{l}\text { FBG, BMI, blood pressure: } \\
\text { both systolic and diastolic }\end{array}$ \\
\hline $\begin{array}{l}\text { Iloon Kashkooli et al } \\
(2015)^{54} \\
\text { Iran }\end{array}$ & $\begin{array}{l}\text { Patients with NAFLD } \\
(\mathrm{n}=80) \text {, including } 32 \\
\text { males and } 48 \text { females }\end{array}$ & $\begin{array}{l}\text { Case and } \\
\text { control }\end{array}$ & $\begin{array}{l}\text { Case group received two } \\
\text { capsules }(750 \mathrm{mg}) \text { every day }\end{array}$ & 3 months & Weight, TGs and TC \\
\hline $\begin{array}{l}\text { Li et al }(20 / 5)^{55} \\
\text { China }\end{array}$ & $\begin{array}{l}\text { Rat model of } \\
\text { metabolic syndrome } \\
(\mathrm{n}=20)\end{array}$ & $\begin{array}{l}\text { Randomized } \\
\text { clinical trial }\end{array}$ & $\begin{array}{l}\text { Case group received } 50 \mathrm{mg} / \\
\mathrm{kg} / \text { day berberine }\end{array}$ & 16 weeks & $\begin{array}{l}\text { P38 MAPK, ATF-2 and } \\
\text { MMP-2 }\end{array}$ \\
\hline $\begin{array}{l}\text { Moazezi and Qujeq } \\
(20 \mid 4)^{56} \\
\text { Iran }\end{array}$ & $\begin{array}{l}\text { Patients with type } 2 \\
\text { diabetes }(n=30)\end{array}$ & $\begin{array}{l}\text { Double-blind } \\
\text { controlled trial }\end{array}$ & $\begin{array}{l}\text { I mg barberry extracts } \\
\text { (capsule) two times per day }\end{array}$ & 8 weeks & FBG, $\mathrm{HbAlc}$ \\
\hline $\begin{array}{l}\text { Pérez-Rubio et al } \\
(2013)^{57} \\
\text { USA }\end{array}$ & $\begin{array}{l}\text { Patients with } \\
\text { a diagnosis of } \\
\text { metabolic syndrome } \\
(n=24)\end{array}$ & $\begin{array}{l}\text { Double-blind } \\
\text { controlled } \\
\text { clinical trial }\end{array}$ & $\begin{array}{l}\text { Twelve patients received } 500 \\
\mathrm{mg} \text { berberine three times } \\
\text { daily and } 12 \text { patients received } \\
\text { placebo }\end{array}$ & 3 months & $\begin{array}{l}\text { Waist circumference, } \\
\text { SBP, TGs and total insulin } \\
\text { secretion }\end{array}$ \\
\hline $\begin{array}{l}\text { di Pierro et al } \\
(20 \mid 2)^{18} \\
\text { Italy }\end{array}$ & $\begin{array}{l}\text { Patients with } \\
\text { suboptimal glycemic } \\
\text { control }(n=22)\end{array}$ & $\begin{array}{l}\text { Pilot clinical } \\
\text { trial }\end{array}$ & $\begin{array}{l}\text { An oral tablet containing } 588 \\
\mathrm{mg} \text { of Berberis aristata extract } \\
\text { titered as } 85 \% \text { berberine and } \\
105 \mathrm{mg} \text { of Silybum marianum } \\
\text { extract titered as } 60 \% \\
\text { flavonolignans }\end{array}$ & 90 days & $\begin{array}{l}\text { HbAIc, TC, LDL-C, TGs, } \\
\text { basal insulin, HOMA-R }\end{array}$ \\
\hline $\begin{array}{l}\text { Hu and Davies } \\
(2010)^{26} \\
\text { USA }\end{array}$ & $\begin{array}{l}\text { Nine-week-old } \\
\text { C57BL/6] male mice } \\
(n=36)\end{array}$ & $\begin{array}{l}\text { Randomized } \\
\text { clinical trial }\end{array}$ & $\begin{array}{l}\text { Groupl: normal diet with } 3 \\
\mathrm{mg} / \mathrm{kg} / \mathrm{day} \text { berberine } \\
\text { Group 2: subgroup I: high-fat } \\
\text { diet; subgroups } 2-4 \text { : high-fat } \\
\text { diet mice treated with } 0.75 \text {, } \\
\mathrm{I.5,} 3 \mathrm{mg} / \mathrm{kg} / \text { day berberine, } \\
\text { respectively }\end{array}$ & 36 days & $\begin{array}{l}\text { Weight gain and food intake, } \\
\text { serum glucose, TG and } \\
\text { TC. Also, downregulation } \\
\text { of PPAR- } \gamma \text { expression and } \\
\text { upregulation of GATA-3 } \\
\text { expression }\end{array}$ \\
\hline $\begin{array}{l}\text { Ebrahimi-Mamaghani } \\
\text { et al }(2009)^{58} \\
\text { Iran }\end{array}$ & $\begin{array}{l}\text { Patients with type } 2 \\
\text { diabetes }(n=57)\end{array}$ & $\begin{array}{l}\text { Randomized } \\
\text { controlled } \\
\text { clinical trial }\end{array}$ & - & 8 weeks & LDL-c and TC/HDL-c ratio \\
\hline $\begin{array}{l}\text { Yin et al }(2009)^{34} \\
\text { China }\end{array}$ & $\begin{array}{l}\text { Patients with type } 2 \\
\text { diabetes }(n=36)\end{array}$ & $\begin{array}{l}\text { Randomized } \\
\text { clinical trial }\end{array}$ & $\begin{array}{l}500 \mathrm{mg} \text { berberine three times } \\
\text { daily }\end{array}$ & 3 months & $\begin{array}{l}\text { HbAIc, FBG, postprandial } \\
\text { blood glucose and TGs }\end{array}$ \\
\hline
\end{tabular}

Abbreviations: ATF-2, activating transcription factor 2; BMI, body mass index; FBG, fasting blood glucose; HbAIc, hemoglobin Alc; HDL-c, high-density lipoproteincholesterol; HOMA-R: homeostatic model assessment-insulin resistance; LDL-c, low-density lipoprotein-cholesterol; MMP-2, matrix metalloproteinase 2; NAFLD, nonalcoholic fatty liver disease; TC, total cholesterol; TGs, triglycerides. 
(Cip1) signaling and Ras/Rac1/Cyclin D/Cdks and inhibiting PDGF-stimulated migration by Rac1 and also inhibiting $\mathrm{Cdc} 42$, resulting in antiproliferative and antimigratory activity. ${ }^{51}$ Berberine suppresses the synthesis of fibronectin and collagen by $\mathrm{p} 38$ MAPK pathway ${ }^{40}$ and prevents the migration and regrowth of smooth muscle cells via inactivating mitogen-activated protein kinase/extracellular signal regulated kinase/early growth response gene 1 (MEK1,2/ ERK/Egr1 signaling pathway) and decreasing Erg1, cFos, cyclin-D and PDGF-A levels. ${ }^{52}$ Lysophosphatidylcholinestimulated vascular smooth muscle cell proliferation and migration is inhibited by activation of ERK1/2 pathway (one of the three MAPK groups). ${ }^{53}$

In Table 2, some human and animal studies related to the effect of berberine and barberry in obesity and MetS are summarized. Some clinical trials used berbeine and some used barberry juice. Most of the studies that explained the molecular mechanisms were conducted in animal models and the molecular mechanisms in humans are not explained.

\section{Conclusion}

According to this study, berberine as a major antioxidant component of B. vulgaris, suppresses adipocyte differentiation and decreases obesity. Also, it regulates glucose metabolism via decreasing insulin resistance and increasing insulin secretion. Berberine also has antihyperlipidemic and antihypertensive effects and protects the endothelium, thereby reducing the risk factors of MetS. In conclusion, $B$. vulgaris may be effective in treatment of obesity and MetS, but more human clinical trials are needed to judge about its effectiveness in this issue because most of the studies explaining the molecular mechanisms were conducted in animal models. Also, some clinical trials used berbeine and some others used barberry juice, so we suggest that studies should be conducted to compare the efficacy of berbeine and barberry juice. We do not know whether these effects of berberine are dose dependent or not; therefore, to clarify the effective doses, more studies are needed.

The perspective studies work on the isolation or neosynthesis of berberine analogs with a higher bioavailability. The scientist can then clarify the mechanism of action of berberine on glucose and lipid metabolism. The possible action of berberine is as a modulator of a gene involved in more processes or as a gene regulator (eg, the upstream stimulatory factors). Anyway, the effect of berberine on PCSK9 modulation is another potential therapeutic target, because berberine strengthens the effects of available antihyperlipidemic drugs. The antihyperlipidemic and antidiabetic effects of berberine are studied through improvement in organ damage in humans (ie, by evaluating their effect on microalbuminuria or arterial stiffness).

\section{Disclosure}

The authors report no conflicts of interest in this work.

\section{References}

1. Larsen MA, Goll R, Lekahl S, Moen OS, Florholmen J. Delayed clearance of triglyceride-rich lipoproteins in young, healthy obese subjects. Clin Obes. 2015;5(6):349-357.

2. Kral JG, Heymsfield S. Morbid obesity: definitions, epidemiology, and methodological problems. Gastroenterol Clin North Am. 1987;16(2):197-205.

3. Kumanyika SK, Obarzanek E, Stettler N, et al. Population-based prevention of obesity: the need for comprehensive promotion of healthful eating, physical activity, and energy balance: a scientific statement from American Heart Association Council on Epidemiology and Prevention, Interdisciplinary Committee for Prevention (formerly the expert panel on population and prevention science). Circulation. 2008;118(4):428-464.

4. Nguyen DM, El-Serag HB. The epidemiology of obesity. Gastroenterol Clin North Am. 2010;39(1):1-7.

5. Macdonald KG. Overview of the epidemiology of obesity and the early history of procedures to remedy morbid obesity. Arch Surg. 2003;138(4):357-360

6. Galgani J, Ravussin E. Energy metabolism, fuel selection and body weight regulation. Int J Obes. 2008;32(Suppl 7):S109-S119.

7. Gibson TM, Ehrhardt MJ, Ness KK. Obesity and metabolic syndrome among adult survivors of childhood leukemia. Curr Treat Options Oncol. 2016;17(4):17.

8. Alberti KG, Zimmet PZ, Pf Z. Definition, diagnosis and classification of diabetes mellitus and its complications. Part 1: diagnosis and classification of diabetes mellitus provisional report of a WHO consultation. Diabet Med. 1998;15(7):539-553.

9. Expert Panel on Detection, Evaluation, and Treatment of High Blood Cholesterol in Adults. Executive summary of the third report of the National Cholesterol Education Program (NCEP) expert panel on detection, evaluation, and treatment of high blood cholesterol in adults (Adult Treatment Panel III). JAMA. 2001;285(19):2486-2497.

10. Desroches S, Lamarche B. The evolving definitions and increasing prevalence of the metabolic syndrome. Appl Physiol Nutr Metab. 2007;32(1):23-32.

11. Kolovou GD, Anagnostopoulou KK, Salpea KD, Mikhailidis DP. The prevalence of metabolic syndrome in various populations. Am J Med Sci. 2007;333(6):362-371.

12. Anis KV, Rajeshkumar NV, Kuttan R. Inhibition of chemical carcinogenesis by berberine in rats and mice. J Pharm Pharmacol. 2001;53(5):763-768.

13. Gurib-Fakim A. Medicinal plants: traditions of yesterday and drugs of tomorrow. Mol Aspects Med. 2006;27(1):1-93.

14. Rounsaville TJ, Ranney TG. Ploidy levels and genome sizes of Berberis L. and Mahonia Nutt. species, hybrids, and cultivars. HortScience. 2010;45(7):1029-1033.

15. Mokhber-Dezfuli N, Saeidnia S, Gohari AR, Kurepaz-Mahmoodabadi M. Phytochemistry and pharmacology of Berberis species. Pharmacogn Rev. 2014;8(15):8.

16. Arayne MS, Sultana N, Bahadur SS. The berberis story: Berberis vulgaris in therapeutics. Pak J Pharm Sci. 2007;20(1):83-92.

17. Abd El-Wahab AE, Ghareeb DA, Sarhan EE, Abu-Serie MM, El Demellawy MA. In vitro biological assessment of Berberis vulgaris and its active constituent, berberine: antioxidants, anti-acetylcholinesterase, anti-diabetic and anticancer effects. BMC Complement Altern Med. 2013;13:218. 
18. di Pierro F, Villanova N, Agostini F, Marzocchi R, Soverini V, Marchesini G. Pilot study on the additive effects of berberine and oral type 2 diabetes agents for patients with suboptimal glycemic control. Diabetes Metab Syndr Obes. 2012;5:213.

19. Choi BH, Ahn IS, Kim YH, et al. Berberine reduces the expression of adipogenic enzymes and inflammatory molecules of 3T3-L1 adipocyte. Exp Mol Med. 2006;38(6):599-605.

20. Zhao W, Xue R, Zhou ZX, Kong WJ, Jiang JD. Reduction of blood lipid by berberine in hyperlipidemic patients with chronic hepatitis or liver cirrhosis. Biomed Pharmacother. 2008;62(10):730-731.

21. Mohammadi A, Sahebkar A, Kermani T, Zhilaee M, Tavallaie S, Ghayour Mobarhan M. Barberry administration and pro-oxidant-antioxidant balance in patients with metabolic syndrome. Iran Red Crescent Med J. 2014;16(12):e16786.

22. Potdar D, Hirwani RR, Dhulap S. Phyto-chemical and pharmacological applications of Berberis aristata. Fitoterapia. 2012;83(5):817-830.

23. Giri S, Rattan R, Haq E, et al. AICAR inhibits adipocyte differentiation in 3T3L1 and restores metabolic alterations in diet-induced obesity mice model. Nutr Metab. 2006;3:31.

24. Hu Y, Davies GE. Berberine increases expression of GATA-2 and GATA-3 during inhibition of adipocyte differentiation. Phytomedicine. 2009;16(9):864-873.

25. Tong Q, Tsai J, Hotamisligil GS. GATA transcription factors and fat cell formation. Drug News Perspect. 2003;16(9):585-588.

26. Hu Y, Davies GE. Berberine inhibits adipogenesis in high-fat dietinduced obesity mice. Fitoterapia. 2010;81(5):358-366.

27. Tong Q, Tsai J, Tan G, Dalgin G, Hotamisligil GS. Interaction between GATA and the C/EBP family of transcription factors is critical in GATA-mediated suppression of adipocyte differentiation. Mol Cell Biol. 2005;25(2):706-715.

28. Wang H, Zhu C, Ying Y, Luo L, Huang D, Luo Z. Metformin and berberine, two versatile drugs in treatment of common metabolic diseases. Oncotarget. 2018;9(11):10135-10146.

29. Xie M, Roy R. AMP-activated kinase regulates lipid droplet localization and stability of adipose triglyceride lipase in C. elegans Dauer Larvae. PLoS One. 2015;10(6): 0130480.

30. Jiang SJ, Dong H, Li JB, et al. Berberine inhibits hepatic gluconeogenesis via the LKB1-AMPK-TORC2 signaling pathway in streptozotocininduced diabetic rats. World J Gastroenterol. 2015;21(25):7777-7785.

31. Fan X, Wang J, Hou J, et al. Berberine alleviates ox-LDL induced inflammatory factors by up-regulation of autophagy via AMPK/mTOR signaling pathway. J Transl Med. 2015;13:92.

32. di Pierro F, Putignano P, Villanova N, Montesi L, Moscatiello S, Marchesini G. Preliminary study about the possible glycemic clinical advantage in using a fixed combination of Berberis aristata and Silybum marianum standardized extracts versus only Berberis aristata in patients with type 2 diabetes. Clin Pharmacol. 2013;5:167.

33. Derosa G, Maffioli P, Cicero AF. Berberine on metabolic and cardiovascular risk factors: an analysis from preclinical evidences to clinical trials. Expert Opin Biol Ther. 2012;12(8):1113-1124.

34. Yin J, Xing H, Ye J. Efficacy of berberine in patients with type 2 diabetes mellitus. Metabolism. 2008;57(5):712-717.

35. Wang ZQ, Lu FE, Leng SH, et al. Facilitating effects of berberine on rat pancreatic islets through modulating hepatic nuclear factor 4 alpha expression and glucokinase activity. World J Gastroenterol. 2008;14(39):6004.

36. Yi P, Lu FE, Xu LJ, Chen G, Dong H, Wang KF. Berberine reverses free-fatty-acid-induced insulin resistance in 3T3-L1 adipocytes through targeting IKKbeta. World J Gastroenterol. 2008;14(6):876.

37. Zhou JY, Zhou SW, Zhang KB, et al. Chronic effects of berberine on blood, liver glucolipid metabolism and liver PPARs expression in diabetic hyperlipidemic rats. Biol Pharm Bull. 2008;31(6):1169-1176.

38. Huang $C$, Zhang Y, Gong Z, et al. Berberine inhibits 3T3-L1 adipocyte differentiation through the PPARgamma pathway. Biochem Biophys Res Commun. 2006;348(2):571-578.
39. Li H, Chen $\mathrm{W}$, Zhou Y, et al. Identification of mRNA binding proteins that regulate the stability of LDL receptor mRNA through AU-rich elements. J Lipid Res. 2009;50(5):820-831.

40. Liu W, Tang F, Deng Y, et al. Berberine reduces fibronectin and collagen accumulation in rat glomerular mesangial cells cultured under high glucose condition. Mol Cell Biochem. 2009;325(1-2):99-105.

41. Cameron J, Ranheim T, Kulseth MA, Leren TP, Berge KE. Berberine decreases PCSK9 expression in HepG2 cells. Atherosclerosis. 2008;201(2):266-273.

42. Choi BH, Ahn IS, Kim YH, et al. Berberine reduces the expression of adipogenic enzymes and inflammatory molecules of 3T3-L1 adipocyte. Exp Mol Med. 2006;38(6):599-605.

43. Lazavi F, Mirmiran P, Sohrab G, Nikpayam O, Angoorani P, Hedayati $M$. The barberry juice effects on metabolic factors and oxidative stress in patients with type 2 diabetes: a randomized clinical trial. Complement Ther Clin Pract. 2018;31:170-174.

44. Fatehi-Hassanabad Z, Jafarzadeh M, Tarhini A, Fatehi M. The antihypertensive and vasodilator effects of aqueous extract from Berberis vulgaris fruit on hypertensive rats. Phytother Res. 2005;19(3):222-225.

45. Peychev L. Pharmacological investigation on the cardiovascular effects of Berberis vulgaris on tested animals. Pharmacia. 2005;52(1-2):118-121.

46. Ko WH, Yao XQ, Lau CW, et al. Vasorelaxant and antiproliferative effects of berberine. Eur J Pharmacol. 2000;399(2-3):187-196.

47. Wong KK. Mechanism of the aortic relaxation induced by low concentrations of berberine. Planta Med. 1998;64(8):756-757.

48. Zilaee M, Safarian M, Kermany T, Emamian M, Mobarhan M, Ferns G. Effect of barberry treatment on blood pressure in patients with metabolic syndrome. J Nat Prod. 2015;8:59-63.

49. Pan LR, Tang Q, Fu Q, Hu BR, Xiang JZ, Qian JQ. Roles of nitric oxide in protective effect of berberine in ethanol-induced gastric ulcer mice. Acta Pharmacol Sin. 2005;26(11):1334-1338.

50. Kang DG, Sohn EJ, Kwon EK, Han JH, Oh H, Lee HS. Effects of berberine on angiotensin-converting enzyme and $\mathrm{NO} / \mathrm{cGMP}$ system in vessels. Vascul Pharmacol. 2002;39(6):281-286.

51. Liang KW, Yin SC, Ting CT, et al. Berberine inhibits platelet-derived growth factor-induced growth and migration partly through an AMPKdependent pathway in vascular smooth muscle cells. Eur J Pharmacol. 2008;590(1-3):343-354.

52. Liang KW, Ting CT, Yin SC, et al. Berberine suppresses MEK/ERKdependent Egr-1 signaling pathway and inhibits vascular smooth muscle cell regrowth after in vitro mechanical injury. Biochem Pharmacol. 2006;71(6):806-817.

53. Cho BJ, Im EK, Kwon JH, et al. Berberine inhibits the production of lysophosphatidylcholine-induced reactive oxygen species and the ERK1/2 pathway in vascular smooth muscle cells. Mol Cells. 2005;20(3):429-434.

54. Iloon Kashkooli R, Najafi SS, Sharif F, et al. The effect of Berberis vulgaris extract on transaminase activities in non-alcoholic fatty liver disease. Hepat Mon. 2015;15(2):e25067.

55. Li XX, Li CB, Xiao J, et al. Berberine attenuates vascular remodeling and inflammation in a rat model of metabolic syndrome. Biol Pharm Bull. 2015;38(6):862-868.

56. Moazezi Z, Qujeq D. Berberis fruit extract and biochemical parameters in patients with type II diabetes. Jundishapur J Nat Pharm Prod. 2014;9(2):e13490.

57. Pérez-Rubio KG, González-Ortiz M, Martínez-Abundis E, RoblesCervantes JA, Espinel-Bermúdez MC. Effect of berberine administration on metabolic syndrome, insulin sensitivity, and insulin secretion. Metab Syndr Relat Disord. 2013;11(5):366-369.

58. Ebrahimi-Mamaghani M, Arefhosseini S, Golzarand M, Aliasgarzadeh A, Vahed-Jabbary M. Long-term effects of processed Berberis vulgaris on some metabolic syndrome components. Iran J Endocrinol Metab. 2009;11(1). 
Diabetes, Metabolic Syndrome and Obesity: Targets and Therapy

Diabetes, Metabolic Syndrome and Obesity: Targets and Therapy is an international, peer-reviewed open-access journal committed to the rapid publication of the latest laboratory and clinical findings in the fields of diabetes, metabolic syndrome and obesity research. Original research, review, case reports, hypothesis formation, expert opinion and commentaries are all considered for publication. The manuscript management system is completely online and includes a very quick and fair peer-review system, which is all easy to use. Visit http://www.dovepress.com/testimonials.php to read real quotes from published authors.

Submit your manuscript here: https://www.dovepress.com/diabetes-metabolic-syndrome-and-obesity-targets-and-therapy-journal 